\title{
THE OIC AND TURKEY'S CYPRUS CAUSE
}

\author{
MAHMUT BALİ AYKAN
}

The Organization of the Islamic Conference (OIC) is an intergovernmental organization headquartered in Jeddah, Saudi Arabia. By December 1992 it had fifty-one member states. According to its charter approved in March $1972,{ }^{1}$ it is composed of the Conference of Kings and Heads of State and Government the Conference of Foreign Ministers the General Secretariat, and subsidiary organs. The Conference of Kings and Heads of State and Government is the supreme authority in the Organization.

OIC was established in Rabat, Kingdom of Morocco, on September 25,1969 , when the leaders of the Islamic world was convened in this city on the occasion of the arson perpetrated on August 21, 1969, against the Mosque of Al-Aqsa, the third holy place of Islam, allegedly by the Zionists. According to its charter, the Organization aims to "promote Islamic solidarity" and to "consolidate co-operation" among member states in the political, economic, social, cultural, and scientific fields. From this Charter's perspective, the OIC is primarily concerned with consolidating co-operation among its member states on various Arab-Israeli problems including the Palestinian issue. Eventhough the religion of Islam is considered in the charter as "...a strong factor for rapprochement and solidarity between Islamic people...", the organization itself is not a religious organization but a political forum resembling the United Nations in terms of its rules of procedure. However, Article IX of its charter indicates that the General Secretariat of the Organization shall "consolidate relations between the

${ }^{1}$ Charter of the Islamic Conference and Rules of Procedure of the Organization of the Islamic Conference (Ankara: Turkish Forcign Affairs Ministry Release, July 1991). 
Islamic Conference and the Islamic Organizations of international character and to realize co-operation in the service of the Islamic objectives."

Fifty-one Islamic member states constituting the OIC have different political and social structures, population, size and per capita income. Consequently, they pursue different domestic and foreign policies and do not have identical overall expectations from the organization. They share, however, a common religion and -with the notable exception of Turkeysimilar historical past and traditions. They all belong to the category of developing states of the so-called Third World; and -again Turkey exceptedthey are all non-aligned. Thus, despite their above-mentioned differences, they share same views and aspirations on variety of international issues like colonialism, racial discrimination, disarmament and new international economic order. Resolutions adopted by the Summit Conferences and Foreign Ministers' meetings of the OIC as well as its charter are based on the same principles as those upheld by the Conference of Non-Aligned countries.

Turkey has a unique place in the OIC. ${ }^{2}$ It is the only NATO member of the OIC. It is the only member of the OIC that has not yet signed its charter on the grounds that it contravenes both the secular Turkish constitution, which established a clear-cut separation of religious and temporal affairs, and Turkey's international status as a member of the Western Community and NATO ally. Therefore, Turkey is not a de jure full member of the OIC eventhough it is treated as such by the members of the Organization. Because of its secular constitution Turkey does not participate in the functioning of certain principal and subsidiary organs of the OIC that operate on the principles of Islamic law (Shariat) i.e. International Islamic Court of Justice and Islamic Fıqh (Islamic jurisprudence) Academy.

With its growing economy with wide potential and its political stability Turkey distinguishes itself as one of the influential members -like Saudi Arabia, Iran, Pakistan- of the organization. It is one of the participant states at the Rabat Conference of 1969, and serves, since 1984, as the Chairman of the Standing Committec on Economic and Commercial Cooperation (COMCEC); one of the 6 specialized commitees the mandate of which involved "playing an eminent role in determining the policies and defining priorities in vital fields such as economy, commerce..."3 Politically,

${ }^{2}$ See "Türkiye'nin Islam Konferansı tle Ilișkileri" (Turkey's Relations with the OIC) in Islam Konferansı Örgütü (the Organization of the Islamic Conference) (An unpublished document released by the Turkish Foreign Affairs Ministry), pp. 14-16.

${ }^{3}$ See Report of the Secretary General of OIC... on the functioning of the OIC subsidiary organs and specialized and afiliated institutions to the 19th Islamic Conference of 
Turkey took a moderate position in the OIC trying to reconciliate variety of political inclinations on the part of the OIC members. It approves the Declarations of the OIC in so far as they are compatible with the secular Turkish constitution as well as with the fundamental principles of the Western-oriented Turkish foreign policy.

This paper uses Cyprus issue as an example to demonstrate Turkey's objectives vis á vis the OIC, specifically, how Turkey has tricd to utilize the OIC to secure support for its Cyprus cause particularly since the proclamation of the "Turkish Republic of Northern Cyprus" in November 1983 up to the 1990) -December 1992, to be more exact.- What were Turkey's aims in its relations with the OIC on the Cyprus issuc? What methods did Turkey use to influence the members of OIC? How successful was Turkey in achieving its aims? These are the main questions that will be considered in this analysis.

1. Turkey's Overall Perspective On The Cyprus Issue, Its Aims And Methods Utilized To Win The Support Of Islamic States And OIC Prior To The 1970s:

The evolution of the Cyprus conflict could be considered in following successive stages: Prior to the establishment of the Republic of Cyprus in 1960; from the collapse of Zurich-London agreements in 1963 to Turkey's military operation in Cyprus in 1974; from the establishment of Turkish Federated state of Cyprus in 1975 to the proclamation of Turkish Republic of Northern Cyprus in 1983; and from 1983 to the present. The Turkish decision to attend the Rabat Summit of September 1969 -the first international Islamic mecting with a political agenda that Republic of Turkey had ever attended since its establishment in $1923-^{4}$ had been preceded by Turkey's intense diplomatic contacts at bilateral and multilateral levels with Islamic and mostly Third World countries to gain support for its Cyprus cause.

In the course of these contacts the Turkish view on Cyprus ${ }^{5}$, for which Turkish diplomats and statesmen tried to enlist a broad international

Foreign Ministers, Cairo, Arab Republic of Egypt, ICFM/19. $90 / \mathrm{ORG} / 0.5$, (unpublished document released by the OIC), p. 8 .

${ }^{4}$ For a detailed analysis of the evolution of modern Turkey's foreign policy concerning international Islamic Conferences and OIC from 1923 to 1992 see the author's book that will be published in 1994 by the Vantage Press in the US. Its tentative title: The OIC and Islam in Turkish Foreign Policy Toward the Islamic World: 1960-1992.

${ }^{5}$ See T.C. Dışişleri Bakanlığı Belleteni: (The Bulletin of the Turkish Foreign Affairs Ministry). [Hereafter cited as Dışişleri Belleteni], No. 14 (November 1965), pp. 63-4. Ibid., No. 15 (December 1965), pp. 42-3. 
support, could be summarized as follows. The breakout of intercommunal fighting between Greek Cypriots and the Turkish Cypriot minority in Cyprus in December 1963 following the declaration of the Greck Cypriot President Archbishop Makarious that Zurich-London agreements were no longer valid, indicated that the creation of bi-communal Republic of Cyprus by Zurich-London agreements of $1959-1960^{6}$ as an independent, non-aligned state, did not mean creation of a new nation of Cyprus. According to the Zurich-London agreements the Turkish Cypriot minority, who, constituted approximately 25 per cent of the population of Cyprus; were Sunni Muslims and spoke Turkish, and Greck Cypriot majority who were Orthodox Christians and spoke Greek, were to be the co-founder partners of the new Republic of Cyprus. They were to be autonomous in their communal affairs and were to partake in the central government on an agreed basis of 7:3., i.c., 7 Greek Cypriot ministers versus 3 Turkish Cypriot ministers. President of the Republic was to be a Greck Cypriot and Vice-President a Turkish Cypriot. The Greck Cypriots, however, had never intended to support this bicommunal structure of the new state. They had considered it as a Greck state and had not renounced their ages-old dream of the union of the island with Greece, called Enosis. They deliberately started the events of 1963 so that Enosis could finally be realized. Let alone the fact that Enosis had been prohibited by the Zurich-London agreements along with taksim-partition of the island by Turkey and Greece-, it would have been, when realized, the slavery for the Turkish Cypriot community who had not intermingled with the Greek Cypriot majority in any field and maintained its cultural and national heritage over centuries. Having been fored out of the government by the Greck Cypriots at gunpoint, the Turkish Cypriot minority were already enduring various kinds of hardships at the hands of the Greck Cypriot government such as economic embargo, restrictions on the frecdom of movement of civilians, unavailability of some essential public service, suffering of refugees and so on.

In the light of all these considerations Turkish statesmen wanted the world community of states to affirm that; the Turkish Cypriots were equal partners to their Greek counterparts; that they deserved all kinds of support of the world community against the Greck Cypriot attempts to dominate them in violation of the Zurich-London agreements; and that the Zurich-London agreements granted Turkey -along with Greece and Great Britain- the "obligation" of intervention in Cyprus should the independence, territorial

See also, Rauf R. Denktaş, The Cyprus Triangle, (London: K. Rüstem \& Brother, 1988), pp. 18-55.

${ }^{6}$ For the texts of these agreements and a study of Cyprus conflict from the perspective of international law see, Sevin Toluner, Kıbrıs Uyuşmazlığı ve Milletlerarası Hukuk (Cyprus Conflict and International Law), (Istanbul: Fakülteler Matbaası, 1977), passim. 
integrity, security and the federal foundations of the Republic is endangered in any way. They wanted the world community to understand that due to its historical ties to the island -the Turkish Cypriot community was the remnant of the Ottoman Turkish rule of the island from 1571 to $1878-$, and due to the geographical proximity of the island to Turkey -strategically located only 40 miles south of Turkey-, Turkey could not be expected to remain indifferent to a drastic change that would occur in the independent status of the island under Enosis. 7

In order to enlist international support of these views Turkey initiated a diplomatic campaign in the Middle East, Asia, Africa and Latin America in 1964. Its dispatched good will missions to these places; high level meetings were arranged with the leaders of the influential Islamic states, like Pakistan and Iran; and Turkey's representatives were sent to attend various NonAligned and Islamic meetings. In the course of this diplomatic campaign the Turkish representatives closely monitored the "tactics" employed by the Greek Cypriots in Non-Aligned mectings to gain international support for their position on Cyprus issue, as well as the responsiveness of the NonAligned states to those tactics. These obscrvations seem to have suggested to the Turks that the Non-Aligned states did not constitute a rigid bloc concerning their individual approaches to and perceptions of the Cyprus issue. Therefore, they could be persuaded to support Turkey's Cyprus cause in international platforms most importantly in the UN, provided that Turkey was willing to support their own causes. ${ }^{8}$ It was within this context the importance of OIC as an intergovernmental organization, whose member states constitutes about one third of the UN and represented in the NonAligned Conference, increased in the eyes of the Turkish statesmen over time. Turkey's presence in the OIC, where Greek Cypriots were not represented, could be used to induce this organization to pass pro-Turkish Cypriot resolutions that would help Turkish cause on Cyprus gain international legitimacy. These resolutions could also be of an important help in inducing the support of the Islamic countries for Turkey's Cyprus cause to counter the Greck Cypriot propaganda offensive in international platforms, particularly in the UN. ${ }^{9}$

\section{The OIC And Turkey's Cyprus Cause In The 1970s:}

The 1970s saw a notable shift in Turkey's role in the OIC mectings from the early reserved stance toward a more active participation. This was the outcome of certain international and external factors, chicfly economic, in nature. As the Turkish economy faced difficulties for various reasons,

\footnotetext{
${ }^{7}$ Dışişleri Belleteni, No. 4, (January 1965), pp. 67-8.

${ }^{8}$ Ibid., No. 3 (October-December 1964), pp. 4, 5, 38-41.

${ }^{9}$ Ibid., p. 4, 5.
} 
including increased oil prices in the wake of the 1973 Arab-Isracli war, Turkish statesmen became more interested in developing Turkey's cconomic ties with the Islamic world than they had been in the 1960s. As a political factor, the US reluctance to support Turkey on the Cyprus issuc, which was revealed in the ill-famed Johnson letter of 1964 -in which President Johnson informed Turkish Premier Inönü that a possible Turkish invasion of Cyprus would not be wise since if it provokes Soviet intervention, the US might not protect Turkey- ${ }^{10}$ had already served as an important factor to strengthen Turkey's approchement with the Islamic world in the 1960s. US imposition of an arms embargo on Turkey in February 1975 to punish in for its military intervention in Cyprus in July 1974, made important contribution to Turkey's further strengthening relations with the Islamic world and the OIC.

Turkey's active participation in the OIC in the 1970s manifested in both political and economic matters. At the level of political co-operation, for example, in contrast to its position during the Rabat Summit of 1969, Turkey openly recognized for the first time the "right" of the people of Palestine to "national independence and sovereignty." in the UN in 1974. ${ }^{11}$ This led to the eventual opening of a PLO office in Ankara in 1979. Turkey also supported Arab positions -including the equation of zionism with racism- in international fora. At the level of economic co-operation, it supported establishment of a common market among the Islamic countrics, no longer finding Turkey's participation in such undertakings incompatible with its links with the EEC, as it did in the 1960s. As the first notable attempt at economic and technical cooperation between Turkey and the Islamic World, under the framework of OIC, the Seventh Islamic Conference of Foreign Ministers of 1976 welcomed the Turkish proposal for the establishment of a statistical, economic and research center for the Islamic countries and a research center on history, art and Islamic culture to be established in Turkey. ${ }^{12}$ These were in fact established in Ankara and in Istanbul in 1978 and 1979, respectively. Turkey also began contributing to the OIC budget in 1974 and participated in the capital of the Islamic Development Bank in 1975, becoming a full member of this bank.

The support Turkey elicited from the OIC on its Cyprus cause was perhaps the most notable achievement of that country from its economic and

${ }^{10}$ See the full text of the Johnson letter of June 1964 in Middle East Journal, Summer 1966, pp. 386-93.

${ }^{11}$ See Mahmut Bali Aykan, "The Palestinian Question in Turkish Foreign Policy From the $1950 \mathrm{~s}$ to the $1990 \mathrm{~s} "$. International Journal of Middle East Studies, 25 (1993), pp. 95-7.

12 See, Declarations and Resolutions of Heads of State and Ministers of Foreign Affairs Conferences (1969-1981), unpublished document of OIC, p. 174. 
political cooperation with the OIC in the 1970s. At first, Sixth Islamic Conference of Foreign Ministers held in Jeddah -Saudi Arabia- in July 1975, to which for the first time Turkey attended with its Foreign Minister, invited Rauf Denktaş -eventhough not as the leader of "Turkish Federated State of Cyprus"- as "the leader of the Turkish Muslim Community in Cyprus" to explain his case before the Conference. The Joint Communique issued by the Conference mentioned this invitation as well as OIC's sympathy for the defense of Turkish Cypriot rights in Cyprus. ${ }^{13}$ Later, in a formal resolution passed for the first time, since the Rabat Summit of 1969, the Seventh Islamic Conference of Foreign Ministers held in Istanbul in May 1976 recognized "the equality of rights of the two Cyprus communitics... and their right to be heard in all international forums." 14 The Istanbul Conference also agreed that the representatives of the "Turkish Muslim Community of Cyprus" be invited to attend future meetings of the OIC as a "guest". Later, the Tenth Islamic Conference of Foreign Ministers held in Fcz, Morocco, in May 1979, not only accepted the change of this guest status to that of "observer" but also called for the OIC members to support the Turkish Cypriot community hurt by the economic embargo imposed on it by the Greek Cypriot leadership of the island. ${ }^{15}$

General Secretariat of the OIC, in its turn, appeared particularly helpful in coordinating the overall support provided by the OIC to the Turks' Cyprus cause. It submitted the decisions of the OIC conference on Cyprus issue to the UN there to be included in the official document and distributed to all members of this organization. It also informed the Islamic Development Bank to provide aid for the Turkish Cypriot community. According to the OIC documents, Islamic Solidarity Fund and all organs of the General Secretariat were providing assistance for Turkish Cypriots; and contacts had been held between the representatives of the Turkish Cypriot Community and President of the Islamic Development Bank, by carly December 1979. ${ }^{16}$

\footnotetext{
13 Ibid., p. 115, see also Ibid., p. 119.

${ }^{14}$ Ibid., p. 168.

${ }^{15}$ Ibid. See also Ibid., p. 409.

${ }^{16} \mathrm{Sec}$ Documents For Political and Information Affairs Eleventh Islamic Conference of Foreing Ministers To be Held in Islamabad, Islamic Republic of Pakistan, ICFM/11-80/PIL/D.5, (unpublished document of OIC), pp. 42-4.
} 
3. Turkish Perspective On The Proclamation of "Turkish Republic Of Northern Cyprus":

In the words of the Turkish Cypriot leader Rauf Denktas following factors contributed to their proclaiming "Turkish Republic of Northern Cyprus" on November 15, 1983. ${ }^{17}$

First, the Greek Cypriot policy of bringing the Cyprus issue to various international platforms, i.e. Non-Aligned movement, Commonwealth Conference and countries, Parliamentary Assembly of the Council of Europe, European Economic Community Countries, UN, violated the Ten Point Agreement reached by the two communities in May 1979, prohibiting such actions. This policy of the Greck Cypriots proved that Greck Cypriot leadership were not interested in a negotiated settlement of the Cyprus issue and was seeking to achieve a unitary rather than a federal system. Second, as the Greek Cypriot view that their administration was the legitimate government of Cyprus and all states must support and help it in its coping with a dispute caused by Turkey's "invasion" of Cyprus gained credibility in international arena ${ }^{18}$ as the result of Greek Cypriot policy of internationalization, the Turkish position on Cyprus issue upholding bizonal, bi-communal federal settlement based on equality of the two communities "...was becoming increasingly impossiblc."

In the light of these considerations the Turkish Cypriot leader calculated that "The way to make the world face reality was to assert [Turkish Cypriots'] right of self-determination and declare... statehood. Only then the world would realize that two nations live in Cyprus and that the Greck Cypriots have no mandate to speak for the Turkish Cypriots." He reasoned that "Recognition was of secondary importance. What was important was to get on the road to recognition. The key to a federal settlement was the assertion of [Turkish Cypriot] nationhood." He believed, "... what mattered above all was that the Turkish Cypriots had asserted their right to sclfdetermination. The fact that this action was being discussed in international circles constituted a fatal blow to the Greck propaganda machine..."

The Turkish statesmen themselves looked surprised by Rauf Denktaş's unilateral move to declare statehood as a tactic to facilitate federal settlement. They had always opposed, since Turkish military intervention in Cyprus in 1974, the inclination of the Turkish Cypriot Icadership to utilize such tactics on the grounds of Turkey's broader interests, i.c., not to jeopardize its well-

${ }^{17}$ See Denktaş, pp. 111, 112, 115, 116, 117, 128, 282-312, 339.

${ }^{18} \mathrm{As}$ an example for such pro-Greek Cypriot UN Resolutions See, Yearbook of the United Nations, 1979, (New York: Office of Public Information, United Nations), p. 431-3. Sec also, Ibid., 1983, pp. 245-6. 
developed ties with the West and swiftly developing relations with the nonWestern world. This time, however, given the nature of Cyprus issue as a matter of national prestige and the sensitivity of Turkish public opinion to it they felt that they had to go along with this "fait accompli."19 Turkey thus became the only state in the world which recognized the Turkish state. It approved the Turkish Cypriot leadership's justifications for and expectations from proclaiming the new state without any reservation and defended and sought international support for them in international arena, most importantly in the UN. ${ }^{20}$ In this respect the perceived importance of the OIC pressed itself once more.

\section{A New Momentum In Turkey's Relations With The} OIC In The 1980s:

From the perspective of Turkey's relations with the OIC, 1980) could be considered in two periods. The period of 1980-1983 saw the importance of the OIC in Turkish foreign policy grow. This fact was largely due to the improvement of the Turkish economy that came in the wake of the military intervention in Turkish politics on September 12, 1980. This intervention brought internal unity and stability into the politically chaotic atmosphere prevailing in Turkey, raising the prestige of Turkey in the OIC. Also, the increase in Turkish exports, brought about by the successful implementation of the economic resolution of January 1980, which was based on domestic production and export promotion, made the markets of the Islamic countries more important than ever for the Turks.

In the period of 1980-1983 Turkey took major leading initiatives in the OIC to contribute to the promotion of economic cooperation among member states. It hosted, for example, a high-level Islamic meeting in Ankara in November 1980 which drafted a common strategy for economic cooperation among the Islamic countries, called the "Plan for Action." At the level of political cooperation a revealing example of Turkish support for the Arab cause came in December 1980, when the Turks reduced for the Arab cause came in December 1980, when the Turks reduced diplomatic relations with Isracl from the level of chargé d'affairs to a minimum level, i.c., the level of second secretary. This was in response to the Isracli decision of July to make Jcrusalem Isracl's capital. 21

\footnotetext{
${ }^{19}$ For details on Turkey's surprise by the Turkish Cypriot declaration of independence see, Foreign Broadcast Information Service, Western Europe Series, November 28, 1983, pp. T2-T3. [Hereafter cited as FBIS. Hereafter, all FBIS citations refer to the Western Europe Series unless otherwise indicated.]

${ }^{20}$ See Denktaş, pp. 313-15.

${ }^{21}$ See Aykan, pp. 100-2.
} 
In the subsequent period beginning in 1984 and extending into the 1990s, relations between Turkey and the OIC full-bloomed. The fundamental international changes brought about by the post Cold-War are -most visibly the collapse of communist regimes beginning in Eastern Europe in 1989offered both advantages and disadvantages for Turkey in accomplishing its foreign policy objectives, in general. On the one hand, the emergence of five Turkic Republics after the collapse of the Soviet Union in December 1991 boosted Turkey's morale and its international prestige in expectation of its strengthening international posture in every field. On the other hand, however, receding communist glacier from the Balkans, Eastern Europe, the Caucasus and Central Asia, left these areas in actual or potential turmoil and created dangerous challenges to regional and world order in various ways, threatening Turkey's national security. In the political, and more specifically security realm the UN became, in the cyes of the Turkish statesmen; the "[Security] umbrella of encouraging it to deal with the regional conflicts upsetting world peace and by contributing to UN's enforcement mechanisms. ${ }^{22}$ In the economic realm, if regionalism were to supplant and undermine globalism with Europe, North America and East Asia emerging as externally closed trading blocks, locking out the developing countries of Africa, Asia and the Middle East -including Turkey- the OIC, with its efforts toward securing free trade among Islamic states could prove to be one of the means of helping Turkey's economic development, in whatever capacity.

The most visible sign of Turkey's blooming relations with the OIC and also if its prestige in the OIC- in this period was Turkey's assumption of the chairmanship of the Standing Committec on Economic and Commercial Cooperation (COMCEC) of the OIC Charter. At the level of political cooperation Turkey made efforts -eventhough with less enthusiasm and success as compared with its activity in the cconomic realm- to contribute to the cooperation of Islamic countries in promoting regional security in the Middle East. It served, for example, in Islamic Peace Committee, set up by the Third OIC Summit of January 1981 to bring about peaceful ending of the Iran-Iraq war. In the post Cold war era, Turkey channelled its activity in cconomic and political realms in the OIC to get this organization actively engaged in contributing to the construction of "a new world order" most notably in the Balkans, the Caucasus and Central Asia.

\section{The OIC And Turkey's Cyprus Cause In The 1980s} And Early 1990s:

The Turkish Cypriots and Ankara government made efforts during the 14th Islamic Conference of Foreign Ministers, held in December 1983 in Dhaka -Bangladesh- by submitting detailed information to the member

${ }^{22}$ See, Hürriyet, June 18,1992, p. 25. 
countries concerning the basic reasons that led the Turkish Cypriot community to declare statchood. Re-emphasizing these reasons, in a speech he made before the Fourth Islamic Summit held in Casablanca in 16-19 January $1984^{23}$, Turkish President Kenan Evren called on all Islamic countries "... to correctly assess the real reasons which compelled the Turkish Cypriots to proclaim an Independent Republic". He added that this proclamation "...should not be considered as an act of secession." The Turks won a political victory when the relevant OIC resolution, unanimously adopted by the Dhaka Conference, -which was later confirmed at the highest level by the Casablanca Summit- satisfactorily fulfilled the Turkish expectations. No mention was made in the Final Communiques issued by these meetings of a recognition accorded to the new Turkish Cypriot state by the OIC. They read, however, "...the Conference expressed sympathy and support for the efforts of the Turkish Muslim Cypriot Community to achieve equal status and to secure their just rights." 24 These words gave, in the words of Mr. Denktaş, a "new strength" to the Turkish Cypriots in defense of their cause and pleased Ankara. ${ }^{25}$ None of them appeared to have expected an early recognition -particularly, de jure recognition- of the new Turkish Cypriot state by Islamic countries. Turkish Cypriots had regarded recognition as "of secondary importance", as mentioned previously and Ankara government expressed its conviction that it would come in time. ${ }^{26}$

After the encouragement of Dhaka and Casablanca resolutions the Turkish Cypriots and Ankara government expected from the OIC and its members a de facto -if not de jure- recognition of the new Turkish Republic of Cyprus by establishing relations with it in "...political, cconomic, diplomatic, commercial and cultural fields and in tourism." 27 As Rauf Denktaş put it "The Turkish Cypriots view[ed] even their between the two communities to be among the fundamental prerequisites of a balanced and harmonious relationship with the Greek Cypriots. They therefore approach international recognition and assistance to the Turkish Cypriot side as a factor capable of making an important contribution towards a settlement in Cyprus."28

${ }^{23}$ Speech By His Excellency President Kenan Evren, President of the Republic of Turkey, at the 4th Islamic Summit Conference, 1618 January 1984. (unpublished document of OIC), pp. 10-11.

${ }^{24}$ See, Final Communique of the Fourth Islamic Summit Conference, Casablanca, (16-19 January 1984) IS/484/F/DEC (unpublished document of the OIC), p. 7.

${ }^{25}$ Denktaş, p. 147

${ }^{26}$ See FBIS, November 29, 1983, p. T1.

27 See Denktaş, pp. 151-2, 393.

28 Ibid. 
The subsequent years following Casablanca summit mecting did not sec a full satisfaction of these Turkish expectations from the OIC. The Final Communique of the Twenticth Islamic Conference of Foreign Ministers held in Istanbul, Turkey, on 4-8 August 1991, however, produced promising signs for their fulfillment in the future. The application of the Turkish Cypriot Community for full membership was not accepted, despite the personal lobbying efforts of the Turkish foreign minister revealing positive results, ${ }^{29}$ by this conference. The Conference adopted, however, a proTurkish Cypriot draft resolution, jointly prepared, for the first time in the history of the OIC, by Saudi Arabia, Pakistan, Somalia and Alghanistan Islamic States sympathetic to Turkey's Cyprus cause- all cooperating with Turkey. ${ }^{30}$ According to this resolution the Conference decided following. It decided, "... to remain seized of [this] request of the Turkish Muslim Community of Cyprus." Also, the "Turkish Community of Cyprus" was granted by this conference representation in all organs of the OIC, and the right to participate in all activities of the OIC. This, the Turks considered as "unnamed full membership." 31

Likewise, although Islamic countrics in general withheld their economic and financial support from Turkish Republic of Northern Cyprus, the United Arab Emirates accepted "in principle" during the Istanbul Conference of August 1991 to open a bureau of representation (of trade and tourism) of the Turkish Cypriot state on its territory. With the actual opening of this burcau in March 1992, UAE become the Second Islamic country thus far, after Pakistan, which had allowed the Turkish Cypriot state to open a similar bureau in Islamabad in 1988 , to grant the Turkish Cypriot state such a right. The Turks hoped that if opened, this bureau would broaden the range of activities and move from the area of tourism into the areas of commerce, economics and culture, in order to strengthen relations between Turkish Republic of Northern Cyprus and the UAE. ${ }^{32}$ Furthermore, the same conference also decided, for the first time, "to call on and urge the member states to increase and expand their relations with the Turkish Muslim Community of Cyprus in all ficlds and in particular in the fields of trade, tourism, information, investment and sports." 33 The Conference also decided, again for the first time, to "request the Islamic Development Bank to

${ }^{29}$ See FBIS, Near East and South Asia Series, 5 August, 1991, pp. 1, 6.

${ }^{30}$ See FBIS, 12 August 1991, p. 44.

${ }^{31}$ See Cumhuriyet, August 4, 991, pp. 1, 15. See also Ibid., August 6, 1991, pp. 1, 15 and Ibid., August 10, 1991, p. 8.

32 See Milliyet, August 11, 1991, p. 11.

33 See Resolutions on the Political Legal and Information Affairs of Foreign Ministers Meeting Held in Istanbul, Republic of Turkey, on 4-8 August 6, 1991, ECFM/2091/RES FINAL, (unpublished document of the OIC), pp. 77-9. 
undertake in consultation with the Turkish Muslim Community of Cyprus a comprehensive study on their economic situation and needs with a view to promoting their economic development." 34 The "reaffirmation" of these resolutions and declarations of the Istanbul meeting on Cyprus by the Sixth Islamic Summit held in Dakar -Senegal- in December 1991, at the highest level, despite the intensive efforts of the pro-Cyprus lobby headed by the Algerian, Egyptian and Palestinian delegations, crowned the diplomatic victory achieved by the Turkish in the Twentieth Conference of August 1991. 35

6. The Attitudes of The OIC Member Countries In The Un On Cyprus Issue Prior To The Proclamation of The "Turkish Republic Of Northern Cyprus" And Afterwards:

As indicated by the attitudes of certain Islamic countries in Istanbul Conference of August 1991 and Dakar Summit of December 1991, the overall support provided by the Resolutions and General Secretariat of the OIC since the 197()s on for Turkey's Cyprus cause could not be regarded as reflecting a uniformity of the policies pursued by individual Islamic states on the Cyprus question. Their voting performances and attitudes during the UN deliberations on the Cyprus issue since 1960)s up to the 1990s clearly reveal this fact. On close cxamination, as we will do below, it could be seen from these performances and attitudes that the composition of "allies", "neutrals" and "opponents" of Turkey's Cyprus causc among the Islamic states has not changed overall -with certain exceptions- since the 1960s up to the 1990s.

UN Security Council Resolution 541 of November 1983 appcars to be nothing but a culmination of UN General Assembly and Security Council resolutions reflecting the views of Greck Cypriots and government of Greece on Cyprus issue since the 1960)s. Resolution 541 "considered" the proclamation of Turkish Republic of Northern Cyprus as "legally invalid", "deploring" that it constituted as "secession of part of the Republic of Cyprus."; "call[ed] for its withdrawal"; "call[ed] upon all states not to recognize any Cypriot state other than the Republic of Cyprus," and "call[ed] upon the parties to co-operate fully with the Secretary General in his mission of Good Offices." 36 Prior to Turkey's military intervention in Cyprus in 1974 and the subsequent declaration of "Turkish Federated State of Cyprus" in 1975, these resolutions had opposed "... any intervention directed against

\footnotetext{
${ }^{34}$ Ibid.

35 Sce, Final Communique of the Sixth Islamic Summit Conference, Dakar, Republic of Senegal, (9-11 December 1991), IS/6-91/FC/FINAL, (unpublished document of OIC), p. 15. See also FBIS, Near East and South Asia, December 9, 1991, p. 24.

${ }^{36}$ Yearbook of the UN, 1983, p. 254.
} 
[Cyprus]" implying, therefore, the obliteration of the Turkish right of intervention granted to it by the Zurich-London agreements of $1960 .{ }^{37}$ In the following period extending from 1974 to the proclamation of "Turkish Republic of Northern Cyprus" in November 1983, UN Resolutions had "demand[ed] the withdrawal without further delay of all foreign armed forces.. and personnel from the Republic of Cyprus". ${ }^{38}$ As bicommunal talks did not lead to a negotiated settlement of the Cyprus problem, -beyond producing a fourth-point agreement in February 1977 and ten-point agreement in May 1979-, General Assembly Resolutions, beginning with the one adopted on November 9, 1978, and Security Council Resolutions up to the one (789) adopted on November 25, 1992 tended to internationalize the Cyprus problem by seemingly broadening the scope of negotiations beyond intercommunal talks through attempts to include General Assembly, Security Council and Secretary General of the UN in the negotiation process. ${ }^{39}$ They also recognised Greck Cypriot administration as the legitimate government of Cyprus and called on all states to support and help it. In this context, it is true, Security Council Resolution 649 of March 1990 was the first UN Resolution recognizing to the pleasure of the Turks- the existence of two politically equal communities in Cyprus and the necessity of solving Cyprus problem on the basis of a "bicommunal and bizonal federation". However, neither this resolution nor the following ones recognized the right of selfdetermination of Turkish Cypriots as a separate people and the right of separate sovereignty for the Turkish Republic of Northern Cyprus which Turkish Cypriots have not abandoned to this day as the sine qua non of a Federal Solution in Cyprus. ${ }^{40}$

Of the two Islamic countries participating in the voting of the UN Security Council Resolution 541 of November 1983, Pakistan voted against it and Jordan abstained. Following the adoption of this Resolution

${ }^{37}$ For example, see UN General Assembly Resolution 2077. Ibid., 1965, p. 213. For Turkey's reaction against this resolution see, Dışişleri Belleteni, No. 15 (December, 1965), pp. 42-5.

${ }^{38}$ For example, see UN General Assembly Resolution 3395. Ibid., 1975, pp. 300-1.

${ }^{39}$ See UN General Assembly Resolution 33/15. Ibid., 1978, pp. 393-4. See, also, UN General Assembly Resolution 34/30 and Islamic States reactions to it. Ibid., 1979, pp. 427-429, 431/3. For Turkish reactions to UN Security Council Resolution 789, See, Milliyet, November 27, 1992.

${ }^{40}$ For Turkish Cypriot official position on these issue see the letter dated 20 October 1992 from Mr. Osman Ertuğ, representative of the Turkish Republic of Northern Cyprus to Secretary General of the UN, A/47/567 S/24695, (official UN Document), p. 3. See, also, Yearbook of the UN, 1991, p. 93. 
representatives of certain Islamic countries evaluated it in their specches. ${ }^{41}$ The representatives of Islamic countrics of Algeria, Democratic Yemen and Egypt in the UN expressed their full support of it. They said they deplored and condemned the declaration of Statehood by Turkish Cypriots as an illegal and unacceptable act. They also declared their opposition that declaration on the grounds that it heightened the political tension in the Eastern Mediterranean with far reaching implications for the world peace and security. In explaining its vote against the Resolution the representative of Pakistan pointed out that the reference to the intercommunal negotiations had been omitted from the final text thus robbing of an explicit mandate for the Secretary General to promote the intercommunal talks and conciliation. In his turn, representative of Jordan said that the text failed to take into account the internal aspect of the Cyprus problem. Jordan's abstention, he explained, stemmed from the unacceptability of this continued one-dimensional approach of the UN to the issue as well as from the unilateral step taken by the Turkish Cypriots.

These speeches and voting performances of Egypt and Algeria as "opponents" of Turkey, "Pakistan" as an ally of Turkey and Jordan as "neutral" on the Cyprus question suggested the continuation of the positions on Cyprus issue these countries have consistently taken -with the notable exception of Algeria- since the 1960s. Among these Pakistan, as a traditionally exceptional ally, have always expressed its "complete solidarity" with Turkey on its Cyprus cause since the 1960s on, voting with Turkey in the UN, except in the period of 1974-1976 when the worldwide negative impact of the Turkish military intervention in Cyprus was perhaps at its climax. ${ }^{42}$ After Pakistan, Iran (as another ally of Turkey in CENTO-the successor of the Baghdad Pact) also consistently and fully supported Turkey's cause in and out of the UN until 1979 when its regime changed from Monarchy to Islamic Republic. Aside from Pakistan and Iran, Islamic states of Saudi Arabia, Bangladesh, Somalia, Malaysia, Afghanistan and Uganda distinguished themselves as inconsistent allies of Turkey by sometimes voting with Turkey in the UN from 1977 on, depending on particular circumstances prevailing at the time as well as on their established positions on Cyprus. ${ }^{43}$

${ }^{41}$ See these evaluations by Islamic States in Ibid., 1983, pp. 254-6.

${ }^{42}$ Sce the text of Turkish-Pakistani Joint Communique of July 1968. Dışişleri Belleteni, No. 46, (July, 1968), pp. 42-3.

${ }^{43}$ The Turkish Foreign Ministry officials told this author that factors ranging from special political concerns of individual Islamic countries to Turkey's one-by-one contacts with their statesmen and diplomats, even the personal attitudes of the representatives of Islamic countries in the UN, might have explained inconsistency in the voting of Islamic countries on Cyprus issue in the UN. Author's interview with Turkish Foreign Ministry officials at the Department of Cyprus, Turkish Foreign Affairs Ministry, Ankara/TURKEY. 
Among the neutrals were Saudi Arabia, Jordan, Afghanistan, Bahrain, Bangladesh, Gambia, Iraq, Kuwait, Malaysia, Maldives, Mauritania, Qatar, Tunisia, United Arab Emirates, Indonesia, Oman, Somalia, Morocco and the Yemen Arab Republic. These states' neutral status was indicated by their consistent or inconsistent -varying from state to state and again depending on particular circumstances prevailing at the time as well as on their established positions on Cyprus- abstaining from voting on pro-Greck Cypriot UN General Assembly resolutions since 1960)s on. Of these states Saudi Arabia, Iraq -became anti- Turkish on Cyprus issue after the Kuwait crisis of August 1990 which strained Iraq's relations with Turkey- Afghanistan and Libya were the notably active ones -even if not consistently- in making efforts to find a compromise during the UN General Assembly deliberations in the OIC and Non-Aligned meetings on the Cyprus issue. ${ }^{44}$ Among these four Islamic states, Saudi Arabia, a moderate Arab state and one of the most influential members of the OIC with traditionally good relations with Turkey and the West, distinguished itself by its consistent active neutrality since 1960's on. Most particularly during the hot UN General Assembly debates on Cyprus question in the 1970s following Turkish military intervention in Cyprus representatives of Saudi Arabia proposed amendments to pro-Greck Cypriot draft resolutions and presented draft resolutions itself that would be acceptable only by Turkey. ${ }^{45}$ For example, this country supported the withdrawal of all foreign armed forces from the island only after two communities reached a negotiated settlement. Similarly she favored inviting Rauf Denktaş to the UN General Assembly in his capacity as "Vice-President of Cyprus" to explain his case there.

As for the rest of the Islamic countries, they were consistent or inconsistent -again varying from country to country- supporters of Greck Cypriot position on the Cyprus issue. Among these Egypt, Syria, -the socalled "progressive", anti-Western and anti-Turkish Arab states of the 1950s-, Lebanon -an internally divided Arab state- and Palestine -perhaps the most adamantly opposed to Turkey's special ties with Isracl among all Arab statesconsistently perpetuated their "opponent" -of Turkey's Cyprus causepositions from 1960s on. A notable change in this group of states occured in the 1970s when Algeria was added to them, having been shifted from an "active ncutrality" role in the 1960), a role she carricd out then with Saudi Arabia, Iraq, Afghanistan and Libya. ${ }^{46}$ In the period following Turkey's

July 26, 1993. See Yearbook of the UN, 1977, p. 366. Ibid., 1978, p. 393. Ibid., 1979, p. 431. Ibid., 1983, pp. 245-6.

${ }^{44}$ See Dişişleri Belleteni, No. 15, (December, 1965), pp. 36-7, 40-3, 969. Ibid., No. 72 (September 1970), pp. 58-9, 83-4.

${ }^{45}$ Sec Yearbook of the UN, 1975, pp. 288-9, 292-3., Ibid., 1977, p. 357.

${ }^{46}$ See Note 44. 
military intervention in Cyprus, Algeria consistently sponsored pro-Greek Cypriot resolutions and acted on behalf of "Contact Group of Countrics" belonging to the Non-Aligned movement in the UN General Assembly delibcration on Cyprus in the 1970s. ${ }^{47}$

These attitudes and voting performances of the Islamic states during the deliberations of UN on Cyprus question prior to the proclamation of the Turkish Cypriot state and afterwards indicate that despite her intense diplomatic contacts with the Islamic countries since 1960s on, both before and after the establishment of the OIC, and despite her increasing role and prestige within the OIC, Turkey has not been able to receive consistent and full support of any Islamic country on its Cyprus cause in the UN in this time span with the single exception of Pakistan. Even Pakistan did not recognize Turkish Republic of Northern Cyprus. There appears to exist variety of reasons for this overall failure. Bclow, we will attempt to clarify them.

\section{Disadvantages of Turkey In Getting Islamic States' Support On Its Cyprus Cause:}

It appears that Turkey had considerable disadvantages in getting full and consistent support of the Islamic countries on its Cyprus cause from the $1960 \mathrm{~s}$ on. One of these was related to the non-aligned international orientation of all Islamic countries. All non-aligned countries, regardless of their differences in their foreign policies, country locations and the fact that the end of Cold War and collapse of the Sovict Union made the term "nonaligned" currently irrevelant in world politics, are opposed to all perceived forms of colonialism. Most non-aligned states had history of domination by some colonial power and of national boundaries having been artifically set by outsiders. Many Non-Aligned African and Asian nationalist leaders, Muslim or Non-Muslim, meticulously refrained from conveying an impression of extending any support to former colonialist states, an act that would be incompatible with the principle of national self-determination, independence, territorial integrity that they all upheld. ${ }^{48}$ It appeared that this sensitivity to colonialism made all Islamic States receptive to the propaganda of the Greek Cypriots, a comrade in non-aligned movement, to the effect that the Greek Cypriots were struggling for independence in accordance with the principle of national self-determination and for territorial integrity against new colonialist

${ }^{47}$ See Yearbook of the UN, 1975, p. 288, Ibid., 1976, p. 294. Ibid., 1979 , p. 427.

${ }^{48}$ See, K. J. Holsti, International Politics, 5th Edition, (New Jersey: Prentice-Hall International, Inc, 1988), p. 99. 
attempts to subjugate them. According to this argument, ${ }^{49}$ Greck Cypriots were carrying out their anti-colonialist struggle against the colonial power of Britain in the 1950s, and against Turkey in the 1960s. In the 1950s Turkish Cypriots -"rebels" or "terrorists" in Greck Cypriot eyes- had sided with Britain in opposing the struggle for independence by Greek Cypriots and in the early 1960 s they were cooperating with Turkey to divide the island. In this cooperation, Turkey's ultimate objective was to establish its own dominance over part of the island in fulfillment of her own colonialist and expansionist ambitions. Zurich and London agreements and the Turkish allegations to the effect that the security of the Turkish Cypriot minority was at stake in the face of Greek Cypriots' designs to subjugate them, were all used as justifications by the Turkish Cypriots and the Ankara government to achieve their own sinister plans.

This argument, emphasized by Greck propaganda, must have been particularly convincing to the Arab states who had lived as the subjects of the Ottoman Empire for more than three hundred years before they established their own states in the twentieth century. From those times they remembered the Turks as dominecring and brutal. The policies pursued by modern Turkish Republic established by Kemal Atatürk in $1923 \mathrm{secms}$ to have considerably increased Arabs resentment against the Turks. Not only this state dissasociated, in the process of Westernization, the fundamental institutions of state from Shariat (Islamic Law) -an act of blasphemy to Arabs for whom Islam was inseparable part of their identity, but also with the consent of colonialist France, mandatory power of the interwar years, the district of Alexandretta gradually seceded from Syria and ultimately incorporated into Turkey in 1939, under the name of Hatay. Hatay issue later created, as variety of issues concerning relationship between Turkey and any Arab country did up to the present, a united front of Arab states, -regardless of their foreign policy differences- against Turkey. 50

All these historical factors causing Arab resentment against the Turk were added by the perceivedly rigid pro-Western line that Democrat Party Administration pursued in the Middle East in the 1950s. Then, Arab States, particularly Egypt, as one of the most prestigious Arab State, and Palestinians, expected support from Turkey in their struggle against Isracl, but were confronted with the rejections of the Turks. The Turks were reluctant to provide the expected support not so much because of their indifference to the Arab cause, but because they saw Sovict Union and not

${ }^{49}$ See examples of such Greek arguments in Yearbook of the UN, 1975, p. 277; Ibid., 1980, p. 451; Dışişleri Belleteni: No. 15, (December, 1965), p. 40.

${ }^{50}$ See Murat Bardakçı in "Uneasy Friends: The Arabs and US" in Hürriyet, August 21, 1989, p. 5. Ibid., August 22, 1989, p. 5. 
Israel as the primary threat to the security of Turkey in particular, and of the region, in general. ${ }^{51}$ Due to this Turkish attitude, combined with the effect of all the above-mentioned historical-psychological factors, Turkey's request for Arab states' support on the Cyprus issue in mid-1960s seems to have appeared as self-secking to the Arabs, as it probably did to them in 1950s when they did not support Turkey on Cyprus issuc in the UN. At least equally important to these considerations appears to be the resemblences between the respective positions of Jews in Palestine and Turkish Cypriots in Cyprus: Both being the late comers to their respective places, as perecived by the Arab states. 52

Aside from their common sensitivity to the issue of colonialism many Islamic countries also had common troubles with internal disunity as it was the case in Cyprus. Similar to the case in Cyprus they experienced the painful process of nation building at home where they have been torn apart by religious, tribal and language conflicts or various differences. Including among such Islamic States were not only African States -which, apart from their similar internal characteristics, were not located near Turkey and did not have much relations with that country- and one of Turkey's consistent Middle Eastern opponents; Lebanon, but also the Central Asian Turkic states of former Soviet Union who also have not recognized the Turkish Republic of Northern Cyprus. ${ }^{53}$

To these disadvantages, were added Turkey's successful military intervention in Cyprus on July 20, 1974 and the declaration by the Turkish Cypriots the "Turkish Federated State of Cyprus" on February 13, 1975. No matter how justified these moves were, legally and morally, particularly from Turkish standpoint, suddenly Turkish dominance over at least part of Cyprus through the establishment of a separate Turkish Cypriot state, in short, a permanent division of the independent state of Cyprus, appeared as a distinct possibility as a result of them. From 1974 on the Greck Cypriot representatives of Cyprus and representatives of Greece joined their forces in the Non-Aligned Conference and the UN to play on the sensitivity of all states-regardless their religion or international orientation- on this possibility, presenting permanent division of Cyprus as a reality. ${ }^{54}$ This Greek Cypriot propaganda seemed to have gained credibility further when

${ }^{51}$ See Omer Kürkçüoğlu, Türkiye'nin Arap Ortadoğusu'na Karşı Politikası (1945-1970) (Turkish Foreign Policy Toward the Arab Middle East), (Ankara: Sevinç Matbaası, 1972), pp. 25-136.

52 See Nuri Esen in Günaydın, March 28, 1982, p. 7.

${ }^{5} 3$ See, Dişişleri Belleteni, No. 15, (December, 1965), p. 96. p. 96, FBIS, Near East and South Asia, 2 August, 1991, p. 5, Hürriyet, October 23,1992 , p. 22.

${ }^{54}$ See Note 49. 
Turkish Cypriots proclaimed "Turkish Republic of Northern Cyprus" in November 1983. UN Security Council Resolution 541 of November 1983 case as the culmination of Greck Cypriot political victories prior to that date in extracting Resolutions from the UN, reflecting their views on the Cyprus question.

As in the case of the preceding developments, the proclamation of statehood could have been morally and legally justified from the standpoint of the Turks. The fact, however, was that combined with ecrtain other factors it made even a single Islamic States' support of Turkey's Cyprus cause from then on increasingly difficult if not impossible. Up to that time the existence of the considerable number of neutral Islamic countries on the Cyprus showed that about half of the members of the OIC -21 out of 42 members (in 1984)- were not indifferent to Turkey's Cyprus cause. However, following considerations appears to have increasingly prevented all Islamic states from de jure recognizing the Turkish Republic of Northern Cyprus, accepting it as a full member of OIC, and made almost all Islamic States refrain from establishing full-fledged relations with it in all fields.

First, the Islamic countries appeared to have experienced the difficulty of reconciling Turkish Cypriots' invoked right of self-determination with the sacred principles of national unity and territorial integrity in their minds. .55 Second, they felt they could not afford alienating powerful Western and nonWestern permanent members of the Security Council of the UN with whom they had various political and cconomic tics. For example, US had reportedly forced Pakistan and Bangladesh to retract their decision to recognize the Turkish Cypriot state by threatening to terminate all US aid to these countries. ${ }^{56}$ Likewise, similar US initiatives appeared responsible for all members of the OIC, ranging from consistently active ncutral Saudi Arabia to consistent opponent Egypt, to become reluctant to support the application of "Turkish Muslim Community of Cyprus" for full membership of the OIC during the Istanbul Conference of OIC in August 1991.57 Also, one of reasons for the non-recognition of the Turkish Cypriot state by Turkic Republic appears to be related to these states' reluctance to jeopardize their ties with the Russian Federation as well as with the Western States. ${ }^{58}$

Third, the OIC members did not want to undercut the continuing bicommunal talks progressing with the good offices of the Secretary General of

${ }^{55}$ See Yearbook of the UN, 1983, pp. 254-6.

56 See, FBIS, August 5, 1991, p. 41.

${ }^{57}$ Ibid. See also Ibid., August 7, 1991, pp. 52-3.

${ }^{58}$ Hürriyet, October 23, 1992, p. 22. 
the UN which OIC has continuously supported through its resolutions. 59 Resolution 649 of March 1990, had been accepted by the Greck Cypriots and won the praise of Turkish Cypriot leadership due to its previously-mentioned nature. It appears that this wide welcome received by Resolution 649 raised the hopes of Islamic states, as well as others, that resolution of the Cyprus issue was near. They must have been discouraged, therefore, with the continuing lack of progress in bi-communal talks over the insistence of the Turkish Cypriot leadership that Turkish Cypriot state was sovereign, Turkish Cypriot community constituted a people and entitled to self-determination that could be exercised even after the establishment of Federation. Once more the Greek Cypriot counter-thesis emphasizing one sovereign state, one people and one right of self-determination belonging to people of Cyprus ${ }^{60}$ must have appealed to them. Not surprisingly all previously mentioned UN Security Council Resolutions following Resolution 649 were adopted unanimously with all participating Islamic states -among them being neutrals; Morocco and Malaysia- voting in favor.

Fourth, closely related with the third factor, the Turkish Cypriots' continuing to declare Federation as their ultimate objective while reserving at the same time for themselves separate sovereignty and the right of national self-determination that could be exercised even after both of an indecisiveness at best and of a bad faith at worst. On being asked why his country did not recognize the Turkish Cypriot state despite its excellent overall relationship with Turkey, the President of Pakistan Gulan Ishak Khan reportedly remarked that even Turkish Cypriots themselves have not made up their mind as to whether they really want independence. ${ }^{61}$ A final factor could be that not only Republic of Cyprus, represented by Greck Cypriots, was an ally in nonaligned movement, but it was also a promising economic partner for Islamic states who have flourishing economic ties with it. ${ }^{62}$

\section{Conclusion And Prospects For The Future:}

The above-mentioned remark by the President of Pakistan pointed to what appears to be the ultimate tragedy of the Turkish Cypriot position on the Cyprus issue that our analysis implied from the beginning: The Turkish statesmen in Cyprus decply suspected that Greck Cypriots had not abandoned their historical aim of dominating them, ultimately, Icading to Enosis. Yct, they equally decply felt that they could not abandon Federation because of its being internationally recognized ultimate solution of the Cyprus issue, but more importantly because of Turkey's possible negative reaction to such an

${ }^{59}$ FBIS, August 7, 1991, pp. 52-3.

${ }^{60}$ See Hürriyet, March 4, 1990, pp. 3, 14.

${ }^{61}$ Ibid., December 7, 1992, p. 23.

${ }^{62}$ See, for example, the case of Iran in FBIS, December 3, 1992, pp. 65-6. 
attempt on their part. Resulting rigid position of insisting on the rights of separate sovereignty and national self-determination as fundamental conditions for the establishment of federation, an insistence which they regarded nothing more than a legitimate self-defense, locked them, nevertheless, to an impossible position in the eyes of the world community of states. Ankara Government had its own part in this tragedy. It could not risk jeopardizing its well-developed relations with the Western and nonWestern states by being ready to support Turkish Cypriots if they renounced federation and chose for permanent independent statehood. Yet, given the fact that Cyprus issuc had long become a matter of national prestige for Turkey to which Turkish public opinion was quite sensitive, Ankara government did not appear to have much freedom of choice but to support, eventhough reluctantly, the initiatives taken by the Turkish Cypriot leadership that appeared gradually leading toward independence.

Given these locked positions of the Turks on the Cyprus issue and considering the existence of equally strong motivations that have compelled all the Islamic and other states to reject those positions, even the limited support Turkey have been able to receive from the Islamic states both within the OIC and outside it -particularly in the UN- could be regarded as an important political victory for the Turks. Whether and to what extent Islamic states will be willing to establish relations with the Turkish Cypriot state in the future in accordance with the relevant OIC resolutions and following the initiative of Pakistan and United Arab Emirates in this respect, remains to be scen. As for de jure recognition of the Turkish Cypriot state by Islamic states and its acceptance as a full member of OIC, it may not be fortheoming in the foreseable future at least until and unless Turkish Cypriots officially abandon Federation as an ultimate solution securing as well, Turkey's support for this position. 